\title{
Rat Plasma Cell Myeloma
}

National Cancer Institute

\section{Source}

National Cancer Institute. Rat Plasma Cell Myeloma. NCI Thesaurus. Code C125416.

Plasma cell myeloma occurring in a rat. 